\title{
FREE AMINO ACID PROFILES OF HONEY SAMPLES FROM VOJVODINA (REPUBLIC OF SERBIA)
}

\author{
Marijana B. Sakač ${ }^{* 1}$, Pavle T. Jovanov ${ }^{1}$, Aleksandar Z. Marić ${ }^{1}$, Zorica M. Tomičić ${ }^{1}$, Lato L. Pezo ${ }^{2}$, \\ Tamara R. Dapčević Hadnađev ${ }^{1}$, Aleksandra R. Novaković ${ }^{1}$ \\ ${ }^{1}$ University of Novi Sad, Institute of Food Technology, 21000 Novi Sad, Bulevar cara Lazara 1, Serbia \\ ${ }^{2}$ University of Belgrade, Institute of General and Physical Chemistry, 11000 Belgrade, \\ Studentski trg 12/N, Serbia
}

${ }^{*}$ Corresponding author:

Phone: +381214853772

Fax: +38121450725

E-mail address: marijana.sakac@fins.uns.ac.rs

\begin{abstract}
Amino acid profile of four honey types - two monofloral (acacia and sunflower), one polyfloral (meadow honey) and forest honey (honeydew honey) collected from the Autonomous Province of Vojvodina (Republic of Serbia) was determined using ion exchange chromatography. The results showed that proline was the dominant amino acid in all analyzed samples. Other amino acids present in substantial amounts were glutamic acid $>$ phenylalanine $>$ glycine $\geq$ serine in acacia and meadow honey samples, while sunflower was characterized by the presence of higher content of alanine compared to serine. Forest honey samples possessed the highest proline content and also the highest total amino acid content. Based on the amino acid contents, honey samples were classified using chemometric methods (cluster analysis (CA) and principal component analysis (PCA)). CA of different honey types could be applied to group honey types. According to the PCA, honey samples are clearly distinguished and form the specific groups. Therefore, amino acid profile could give an indication of honey botanical origin.
\end{abstract}

Key words: honey, amino acids, botanical origin

\section{INTRODUCTION}

Honey is a supersaturated solution of sugars, in which glucose and fructose dominate (85-95\%), sucrose is present in a small amount (approximately 1\%) and maltose and other oligo- and polysaccharides are present in traces (Alqarni et al., 2012). Honey also contains more than 200 minor substances, including minerals, proteins, enzymes, amino and organic acids, vitamins, polyphenols, and other phytochemicals (Escuredo et al., 2013). Studies have shown that some of these constituents (phenolic acids, flavonoids, ascorbic acid, proteins, and carotenoids) possess antioxidant properties, ensuring the therapeutic effects of honey (AlvarezSuarez et al., 2010).

Proteins and amino acids in honeys derive from animal or vegetal sources (Lee et al., 1985), including fluids and nectar secretions of the salivary glands of honeybees, but pollen represents the main source of proteins (Escuredo et al., 2013). Therefore, the amino acid profile of honey could be characteristic of its botanical origin (Anklam, 1998; da Silva et al., 2016; Hermosín et al., 2003), but it also varied depending on the geographical origin (Cometto et al., 2003). 
The protein content of floral honey varies from 0.1 to $1.5 \%$, while in honeydew honey this quantity is $3.0 \%$ (Czipa et al., 2012; da Silva et al., 2016). Proline is the dominant amino acid in honey (Iglesias et al., 2006), with $50-85 \%$ of the total amino acids (Pawlowska and Armstrong, 1994). Proline is produced by salivary secretion of honey bees during conversion of nectar into honey. Its content in honey constantly decreases during storage and therefore proline might be an indicator of honey ripeness (da Silva et al., 2016). In addition, it is suggested as an indicator of adulteration of honey with sugars, because its content is lowered in sugar adulterated honeys (Bogdanov and Martin, 2002). The minimum level of $180 \mathrm{mg} / \mathrm{kg}$ for proline was internationally accepted for most of the honey types which were not adulterated (Hermosín et al., 2003), except locust honey known to possess low proline content (Flanjak et al., 2016).

Besides proline other amino acids are also present in honey, including glutamic acid, alanine, phenylalanine, tyrosine, leucine and isoleucine being the most common (Girolamo et al., 2012). Other amino acids also detected in different honey types, but in lower amounts were glutamine, histidine, glycine, threonine, arginine, valine, methionine, cysteine, tryptophan, lysine and serine (Hermosín et al., 2003). Kečkeš et al. (2013) determined that the most abundant amino acids in Serbian unifloral honeys were proline, alanine, phenylalanine, threonine and arginine, while Hermosín et al. (2003) found that Spanish honeys contained proline, phenylalanine, tyrosine and lysine as the main amino acids, followed by arginine, glutamic acid, histidine and valine.

Although amino acid profile may serve to determine honey botanical origin, several compounds may be formed from the reaction of the carbonyl group of a reducing sugar with the free amino group of amino acids, peptides or proteins during honey storage or its thermal treatment (Sanz et al., 2003; Zhao et al., 2018). This reaction leads to the depletion of amino acids, whose reduction is the most expressed in the first 9 months (Iglesias et al., 2006).
For that reason, amino acid profile of honey samples (40) of two monofloral honey types (acacia and sunflower), polyfloral honey (meadow honey) and forest honey (honeydew honey) harvested in 2017 in the Autonomous Province of Vojvodina (Republic of Serbia) was evaluated in fresh samples with the aim to 1) contribute to the database of the free amino acid composition of Serbian honeys and to 2) gain knowledge about the possible use of amino acid profile in distinguishing honey types. The investigated honey types were the most frequently produced in Vojvodina and hence selected for this study.

\section{MATERIALS AND METHODS}

\section{Collection of honey samples}

Forty honey samples (10 acacia, 10 sunflower, 10 meadow, and 10 forest) harvested in 2017 from the Autonomous Province of Vojvodina in the Republic of Serbia were used to measure their amino acid content. Honey samples were obtained from traditional beehives. The honey was extracted by hand from the hives using pressure or wooden presses. Approximately $0.5 \mathrm{~kg}$ of each honey sample was purchased directly from the collectors. The samples were stored at room temperature in a dark place until analyses.

\section{Melissopalynological analysis}

Qualitative and quantitative melissopalynological analysis was performed according to the Von der Ohe et al. (2004). Ten grams of the sample was diluted in distilled water, centrifuged, and the resulting sediment transferred to a microscopic slide. After mounting with glycerine-jelly, slides were analyzed using a light microscope at $400 \times$ magnification. In each sample 500 pollen grains were counted and identified using referent slides and pollen identification atlases (Bucher et al., 2004; Moore and Webb, 1978; Reille, 1995; Reille, 1998; Reille, 1999a; Reille, 1999b).

\section{Sample preparation}

Amino acid analyses of honey were performed by ion exchange chromatography using an automatic amino acid analyzer Biochrom 30+ (Biochrom, Cambridge, UK) according to Spackman et al. (1958). The technique was based on amino acid se- 
paration using strong cation exchange chromatography followed by the ninhydrin colour reaction and photometric detection at $570 \mathrm{~nm}$ and $440 \mathrm{~nm}$ (for proline).

Honey samples (3-5 g) were dissolved in ultrapure water $(25 \mathrm{~mL})$. Water was purified using a Crystal EX, Adrona (Riga, Latvia) water purification system and ultrapure water was obtained using a Simplicity UV, Millipore (Molshem, France). The solution of honey was filtered through $0.22 \mu \mathrm{m}$ pore size PTFE filter (Plano, Texas, USA) and the filtrate was transferred into a vial (Agilent Technologies, USA) and stored in a refrigerator prior to analysis.

The amino acid peaks were identified by comparison of retention times with retention times of amino acid standard purchased from Sigma Aldrich (Amino Acid Standard Solution (Sigma-Aldrich, St. Louis, USA)). The results were expressed as $\mathrm{mg} / \mathrm{kg}$ on dry weight basis.

\section{Statistical analysis}

Results were expressed as mean \pm standard deviation of triplicate analyses for amino acid determination. Analysis of variance (ANOVA) for comparison of sample means was used to analyse variations in observed parameters among the samples. All data were processed statistically using the software package STATISTICA 10.0 (StatSoft Inc., Tulsa, OK, USA).

Pattern recognition techniques (Principal component analysis - PCA and cluster analysis - CA) were applied to the experimental data (used as descriptors) to characterize and differentiate among the observed samples.

\section{RESULTS AND DISCUSSION}

Honey authenticity is focused on 1) honey geographical or botanical origin or 2) can be considered in respect of honey production. The determination of honey botanical and geographical origin is a great issue in honey quality control because it contributes in consumer protection and guarantees the product position on the market. Therefore, many efforts have been done to find analytical markers of the botanical (and geographical) origin of honey.
Lazarević et al. (2012) found that basic physicochemical parameters (water content, electrical conductivity, free acidity, optical rotation and $\mathrm{pH}$ ) of some honey types (acacia, sunflower and linden) can be used as a cheap, rapid and reliable tool for modelling the honey botanical origin. Also, Sakač et al. (2019) discovered that acacia honey samples can be clearly grouped in a cluster, while distinguishing of sunflower and meadow honey samples can be possible using principal component analysis (PCA) for their separation based on physicochemical parameters (moisture, acidity, $\mathrm{pH}$, ash, electrical conductivity, glucose, fructose, hydroxymethylfurfural (HMF), colour (CIE $\left.L^{*} a^{*} b^{*}\right)$ ) and mineral content.

Amino acid profile can be considered valuable characteristic of honey botanical origin since pollen represents the main source of honey amino acids (Anklam, 1998). Some papers deal with the possibility to distinguish different honey types using amino acid profile (Hermosín et al., 2003; Kečkeš et al., 2013; Rebane and Herodes, 2008; Sun et al., 2017). Hence, our investigation was directed towards obtaining amino acid profiles of four honey types (10 acacia, 10 sunflower, 10 polyfloral (meadow), and 10 honeydew honey (forest)) harvested in 2017 from the Autonomous Province of Vojvodina (Republic of Serbia) with the aim to differrentiate honeys in botanical groups. The botanical origin confirmation of investigated honey types was presented in Table 1.

Table 2 presents the amino acid profiles of 10 acacia, 10 sunflower, 10 meadow and 10 forest honey samples.

The total amino acid content of examined honey samples varied depending on the type of honey being $1171 \pm 353 \mathrm{mg} / \mathrm{kg}$, $1197 \pm 226 \mathrm{mg} / \mathrm{kg}, 1893 \pm 346 \mathrm{mg} / \mathrm{kg}$ and $2599 \pm 233 \mathrm{mg} / \mathrm{kg}$ for meadow, acacia, sunflower, and forest honey, respectively. Almost all investigated amino acids were detected in honeys collected from Vojvodina (with the exception of aspartic acid in sunflower and forest honey samples and threonine in sunflower honey samples) including sulphur-containing amino acids, which were not detected in Estonian (Rebane and Herodes, 2008) and Chinese 
honeys (Sun et al., 2017), but identified in Spanish and French honeys (Hermosín et al., 2003; Cotte at al., 2004). Total amino acid con-tent of our honey samples was higher than in Estonian and French honeys (Cotte at al., 2004; Rebane and Herodes, 2008).

The dominant amino acid in all investigated honey samples was proline contributing approximately $46 \%, 41 \%, 39 \%$ and $33 \%$ in acacia, meadow, sunflower and forest honey, respectively. Its contribution is lower than cited by Pawlowska and
Armstrong (1994), who reported that proline represented $50-85 \%$ of the total amino acids in honeys. Also, Sun et al. (2017) found that proline accounted for $50 \%$ in Chinese honeys.

Proline content in all investigated honey samples was above $180 \mathrm{mg} / \mathrm{kg}$, which is defined as the minimum level accepted for honeys of superior quality (Hermosín et al., 2003). Proline content was the highest in forest honey samples compared to other investigated mono- and polyfloral honeys (Table 2).

Table 1.

Results of melissopalynological analysis

\begin{tabular}{|c|c|c|}
\hline $\begin{array}{l}\text { Type of honey and } \\
\text { number of samples }\end{array}$ & Dominant pollen type & Subdominant pollen type \\
\hline Acacia $(10)$ & $\begin{array}{l}>30 \% \text { Fabaceae } \\
\text { Robinia pseudoacacia }\end{array}$ & Fraxinus, Brassicaceae \\
\hline Sunflower (10) & $\begin{array}{l}>40 \% \text { Asteraceae } \\
\text { Helianthus annuus }\end{array}$ & Brassicaceae, Fabaceae \\
\hline Meadow (10) & - & $\begin{array}{l}\text { Asteraceae, Brassicaceae, } \\
\text { Fabaceae, Lamiaceae }\end{array}$ \\
\hline Forest (10) & - & - \\
\hline
\end{tabular}

Table 2.

Amino acid profiles of different honey types (acacia, sunflower, meadow, and forest) collected at several locations in the Autonomous Province of Vojvodina (Republic of Serbia) (mean values and standard deviations, minimum and maximum values)

\begin{tabular}{|c|c|c|c|c|c|}
\hline \multirow[b]{2}{*}{$\begin{array}{l}\text { Amino acid } \\
(\mathrm{mg} / \mathrm{kg})\end{array}$} & \multirow[b]{2}{*}{ Parameter } & \multicolumn{4}{|c|}{ Type of honey and number of samples } \\
\hline & & $\begin{array}{c}\text { Acacia } \\
(10)\end{array}$ & $\begin{array}{c}\text { Sunflower } \\
\text { (10) }\end{array}$ & $\begin{array}{c}\text { Meadow } \\
(10)\end{array}$ & $\begin{array}{c}\text { Forest } \\
(10)\end{array}$ \\
\hline \multirow[t]{3}{*}{ Aspartic acid } & Mean value \pm SD & $30.3 \pm 51.4^{a}$ & $0.00 \pm 0.00$ & $15.9 \pm 35.5^{a}$ & $0.00 \pm 0.00$ \\
\hline & Min & 0 & 0.00 & 0 & 0.00 \\
\hline & Max & 139 & 0.00 & 104 & 0.00 \\
\hline \multirow[t]{3}{*}{ Threonine } & Mean value \pm SD & $7.02 \pm 15.1^{a}$ & $0.00 \pm 0.00$ & $6.49 \pm 14.4^{a}$ & $13.9 \pm 19.5^{\mathrm{a}}$ \\
\hline & Min & 0 & 0.00 & 0 & 0.00 \\
\hline & Max & 48.0 & 0.00 & 41.7 & 61.7 \\
\hline \multirow[t]{3}{*}{ Serine } & Mean value \pm SD & $51.3 \pm 18.0^{a}$ & $68.7 \pm 19.5^{\mathrm{a}}$ & $56.8 \pm 15.7^{a}$ & $109 \pm 14.0^{b}$ \\
\hline & Min. & 24.6 & 20.4 & 21.5 & 87.6 \\
\hline & Max. & 76.2 & 86.2 & 75.8 & 128 \\
\hline \multirow[t]{3}{*}{ Glutamic acid } & Mean value \pm SD & $100 \pm 41.3^{a}$ & $413 \pm 196^{b}$ & $134 \pm 110^{a}$ & $509 \pm 154^{b}$ \\
\hline & Min. & 13.4 & 103 & 12.6 & 355 \\
\hline & Max. & 155 & 638 & 394 & 794 \\
\hline \multirow[t]{3}{*}{ Proline } & Mean value \pm SD & $543 \pm 176^{\mathrm{ab}}$ & $745 \pm 224^{\mathrm{bc}}$ & $459 \pm 91.8^{a}$ & $863 \pm 210^{c}$ \\
\hline & Min. & 186 & 279 & 299 & 462 \\
\hline & Max. & 745 & 931 & 634 & 1159 \\
\hline \multirow[t]{3}{*}{ Glycine } & Mean value \pm SD & $51.8 \pm 30.5^{a}$ & $70.8 \pm 23.6^{a}$ & $45.5 \pm 25.2^{a}$ & $221 \pm 134^{\mathrm{b}}$ \\
\hline & Min. & 4.40 & 19.3 & 20.4 & 140 \\
\hline & Max. & 97.4 & 95.7 & 101 & 596 \\
\hline \multirow[t]{3}{*}{ Alanine } & Mean value \pm SD & $46.8 \pm 25.2^{a}$ & $109 \pm 24.9^{b}$ & $36.4 \pm 18.7^{a}$ & $111 \pm 25.4^{b}$ \\
\hline & Min. & 7.31 & 80.2 & 10.4 & 74.7 \\
\hline & Max. & 80.3 & 154 & 75.7 & 159 \\
\hline \multirow[t]{3}{*}{ Cystine } & Mean value \pm SD & $22.9 \pm 10.7^{a}$ & $12.4 \pm 5.65^{a}$ & $38.4 \pm 56.8^{a}$ & $18.3 \pm 3.81^{a}$ \\
\hline & Min. & 13.1 & 3.80 & 7.54 & 11.7 \\
\hline & Max. & 41.0 & 22.0 & 193 & 25.9 \\
\hline \multirow[t]{2}{*}{ Valine } & Mean value \pm SD & $30.4 \pm 13.0^{a}$ & $57.0 \pm 31.6^{b}$ & $30.6 \pm 23.7^{a}$ & $109 \pm 11.6^{c}$ \\
\hline & Min. & 4.12 & 19.5 & 5.69 & 96.0 \\
\hline
\end{tabular}




\begin{tabular}{|c|c|c|c|c|c|}
\hline \multirow[b]{2}{*}{$\begin{array}{l}\text { Amino acid } \\
(\mathrm{mg} / \mathrm{kg})\end{array}$} & \multirow[b]{2}{*}{ Parameter } & \multicolumn{4}{|c|}{ Type of honey and number of samples } \\
\hline & & $\begin{array}{c}\text { Acacia } \\
(10)\end{array}$ & $\begin{array}{c}\text { Sunflower } \\
(10)\end{array}$ & $\begin{array}{l}\text { Meadow } \\
\text { (10) }\end{array}$ & $\begin{array}{c}\text { Forest } \\
(10)\end{array}$ \\
\hline \multirow{4}{*}{ Methionine } & Max. & 46.2 & 117 & 73.2 & 129 \\
\hline & Mean value \pm SD & $48.7 \pm 85.6^{\mathrm{a}}$ & $35.2 \pm 24.5^{\mathrm{a}}$ & $30.3 \pm 31.8^{a}$ & $69.7 \pm 36.5^{a}$ \\
\hline & Min. & 0 & 17.7 & 0 & 37.9 \\
\hline & Max. & 283 & 86.6 & 98.4 & 159 \\
\hline \multirow[t]{3}{*}{ Isoleucine } & Mean value \pm SD & $16.5 \pm 8.57^{\mathrm{ab}}$ & $32.9 \pm 18.2^{b}$ & $14.3 \pm 17.3^{\mathrm{a}}$ & $60.1 \pm 8.12^{\mathrm{C}}$ \\
\hline & Min. & 0 & 9.90 & 0 & 49.4 \\
\hline & Max. & 28.3 & 67.6 & 54.8 & 70.7 \\
\hline \multirow[t]{3}{*}{ Leucine } & Mean value \pm SD & $25.3 \pm 15.7^{\mathrm{a}}$ & $61.9 \pm 40.5^{\mathrm{b}}$ & $37.8 \pm 31.3^{\mathrm{ab}}$ & $106 \pm 20.9^{c}$ \\
\hline & Min. & 0 & 30.2 & 3.84 & 75.8 \\
\hline & Max. & 47.4 & 150 & 102 & 136 \\
\hline \multirow[t]{3}{*}{ Tyrosine } & Mean value \pm SD & $18.8 \pm 11.1^{a}$ & $52.0 \pm 77.1^{\mathrm{a}}$ & $72.0 \pm 86.8^{a}$ & $50.1 \pm 26.2^{\mathrm{a}}$ \\
\hline & Min. & 8.14 & 9.05 & 0 & 15.9 \\
\hline & Max. & 43.5 & 268 & 308 & 86.0 \\
\hline \multirow[t]{3}{*}{ Phenylalanine } & Mean value \pm SD & $138 \pm 41.7^{\mathrm{ab}}$ & $135 \pm 29.8^{\mathrm{ab}}$ & $125 \pm 22.6^{a}$ & $169 \pm 39.6^{b}$ \\
\hline & Min. & 97.7 & 92.4 & 93.8 & 117 \\
\hline & Max. & 226 & 193 & 157 & 227 \\
\hline \multirow[t]{3}{*}{ Histidine } & Mean value \pm SD & $19.9 \pm 13.0^{a}$ & $38.1 \pm 5.08^{b}$ & $20.3 \pm 10.9^{a}$ & $43.0 \pm 3.96^{b}$ \\
\hline & Min. & 0 & 29.4 & 0 & 39.0 \\
\hline & Max. & 45.6 & 45.0 & 39.1 & 50.2 \\
\hline \multirow[t]{3}{*}{ Lysine } & Mean value \pm SD & $28.3 \pm 15.8^{a}$ & $48.2 \pm 9.06^{b}$ & $33.2 \pm 22.8^{a b}$ & $84.1 \pm 5.87^{c}$ \\
\hline & Min. & 0.02 & 37.3 & 0 & 77.1 \\
\hline & Max. & 55.2 & 63.5 & 71.7 & 93.4 \\
\hline \multirow[t]{3}{*}{ Arginine } & Mean value \pm SD & $18.3 \pm 11.3^{a}$ & $13.6 \pm 8.42^{\mathrm{a}}$ & $15.5 \pm 16.6^{a}$ & $62.9 \pm 37.5^{\mathrm{b}}$ \\
\hline & Min. & 0 & 1.27 & 0 & 34.6 \\
\hline & Max. & 32.0 & 27.2 & 58.3 & 146 \\
\hline $\begin{array}{l}\text { Total amino } \\
\text { acids }\end{array}$ & Mean value \pm SD & $1197 \pm 226$ & $1893 \pm 346$ & $1171 \pm 353$ & $2599 \pm 233$ \\
\hline
\end{tabular}

Means in the same raw with different superscript are statistically different $(p \leq 0.05)$

The differences between proline content are statistically significant $(p \leq 0.05)$ between meadow and sunflower honeys, meadow and forest honeys, and between acacia and forest honeys, but according to proline content measured in our honey samples this parameter cannot be generally used for distinguishing investigating honey types.

Proline content in honey samples collected at locations from Vojvodina was higher than previously determined contents cited in the literature. Rebane and Herodes (2008) determined $382 \pm 154 \mathrm{mg} / \mathrm{kg}$ proline in polyfloral honeys from Estonia, which is lower than in our polyfloral honey samples $(459 \pm 91.8 \mathrm{mg} / \mathrm{kg}$ in meadow honey) (Table 2).

Proline was followed by other markedly present amino acids: glutamic acid $>$ phenylalanine $>$ glycine $\geq$ serine in acacia and meadow honey samples, while sunflower honey was characterized by higher amounts of alanine compared to serine. Alanine was the fourth most abundant amino acid in sunflower honey samples but glycine content was higher than alanine in forest honey samples (Table 2).

Phenylalanine was found to be the second most abundant amino acid in French and Estonian honey (Cotte et al., 2004; Rebane and Herodes, 2008), while alanine, aspartic acid, glycine, and glutamic acid were also present in substantial amounts (Rebane and Herodes, 2008). Besides proline, Sun et al. (2017) detected tyrosine, serine, alanine and histidine as the main amino acids in acacia honey samples from China, while Kečkeš et al. (2013) found proline, alanine, phenylalanine, threonine and arginine accounted for the majority in Serbian unifloral honeys.

According to the amino acid profiles of acacia, sunflower, meadow, and forest ho- 
neys from Vojvodina (Table 2) it can be concluded that only forest honey samples could be distinguished from other honeys using serine, glycine, valine, leucine, isoleucine, lysine and arginine as the markers for differentiation.

\section{Cluster analysis}

Cluster analysis (CA) was performed to classify examined honey types, e.g. to group honey samples according to their similarity (Gok et al., 2015). The complete linkage algorithm and City block (Manhattan) distances were used to explain the differences in honey types, which were grouped in four clusters (Figure 1). The first cluster contained the most of sunflower honey samples. The second group was consisted of forest honey samples, while the third group contained acacia and meadow samples. The fourth cluster comprised one sunflower and one forest honey sample. Therefore, CA of different honey types (acacia, sunflower, meadow, and forest) could be applied to separate some honey types from others. However, a few observed honey samples are excluded from the clusters in which they should belong according to their honey type.

\section{Principal component analysis}

In this paper, principal component analysis (PCA) was applied to analyse the similarities of four honey types represented by samples collected at several locations in Vojvodina. PCA was used for representtation of amino acid contents in different honey types in a 2-D diagram. According to the results of PCA, the first four principal components have eigenvalues greater than 1 . These four principal components explained $73.62 \%$ of the data variation. The eigenvalues dropped dramatically after the first eigenvalue (the first was 7.89 , while the second and the third were 2.27 and 1.34, respectively), which led to the conclusion that only the first two principal components (explaining 59.79\% of the variation) could be used for the adequate explanation of the data. The cumulative variance accounted for the first and the second principal components was lower than that found by Rebane and Herodes (2008) $(75.35 \%)$, but close to
$64 \%$ for the first three PC variables cited by Hermosín et al. (2003).

The PCA of the presented data explained that the first principal components explained $46.43 \%$ of the total variance, while the second showed $13.36 \%$ in the seventeen variables (amino acids) (Figure 2).

Considering the map of the PCA performed on the data, the negative contribution to the first principal component calculation (PC1) was observed for several amino acid contents: serine (Ser - 9.7\%), glutamic acid (Glu - 8.4\%), alanine (Ala $7.7 \%$ ), valine ( $\mathrm{Val}-11.0 \%$ ), isoleucine (lle - 10.8\%), leucine (Leu - 8.4\%), histidine (His - 9.1\%), and lysine (Lys - 11.4\%). None of the observed variables showed the significantly positive contribution to the PC1.

The contents of cystine (Cys - 17.9\%), methionine (Met $-24.6 \%$ ), tyrosine (Tyr $8.3 \%$ ) and phenylalanine (Phe - 16.1\%) showed the positive influence on the second component calculation (PC2), while the contents of proline (Pro - 20.8\%) and alanine (Ala - $8.7 \%$ ) showed the negative score according to the second principal component. The influence of the contents of aspartic acid (Asp - 12.3\%), threonine (Thr - 39.5\%) and arginine (Arg - 16.5\%) was observed for PC3 calculation.

The PCA analysis shows that the diversity between investigated honey types could be described by the contents of Val, Ile, His, Lys, and Ser (negative contribution to the PC1), and Pro, Phe, Cys, and Met (most influential to the PC1). Forest honey samples are placed on the left side of the PCA graph and they are characterized by the highest Leu, His, Lys, Ile, Ser, Val and GIn contents.

Sunflower honey samples are situated close to the origin of the plot, while acacia and meadow honey samples are positioned at the left side of the graph. According to the PCA, honey samples are clearly distinguished and form the specific groups in the factor plane, and, therefore, their amino acid profiles could give an indication of honey botanical origin, which can be confirmed by determination of other honey parameters. 


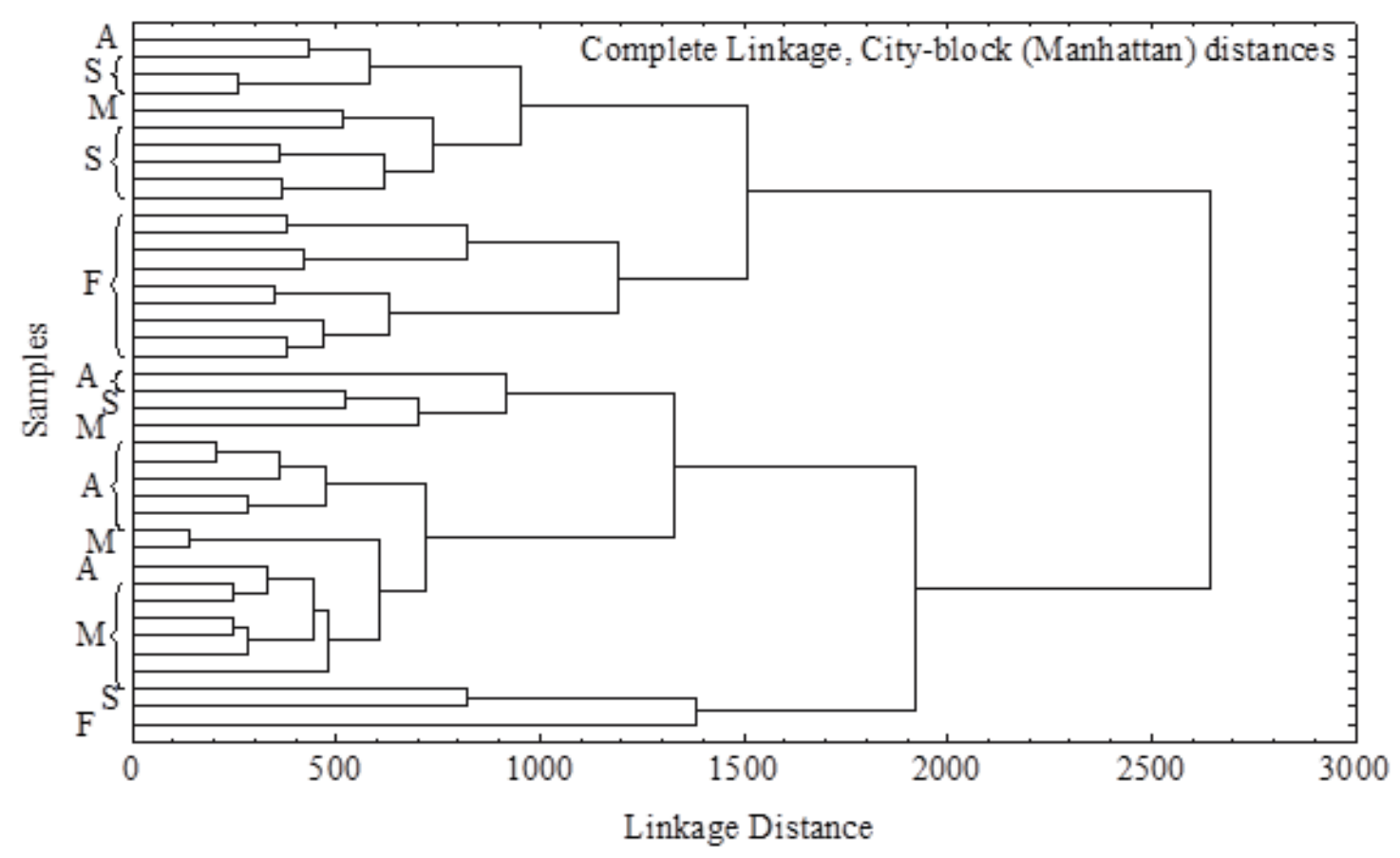

Figure 1. Dendrogram of the cluster analysis of honey samples A - acacia honey; S - sunflower honey; $\mathrm{M}$ - meadow honey; $\mathrm{F}$ - forest honey

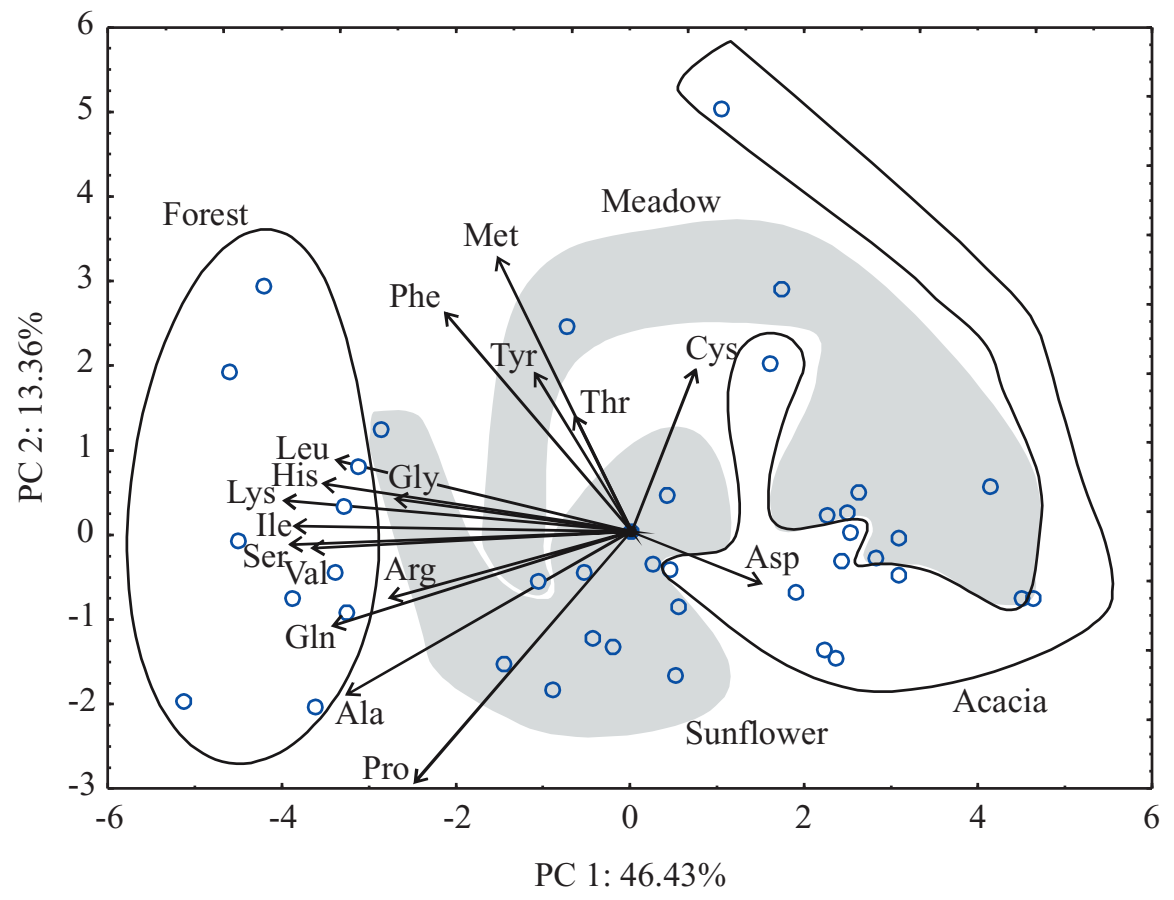

Figure 2. Biplot graphic of amino acids determined in honey samples Ala - alanine; Arg - arginine; Asp - aspartic acid; Cys - cystine; Gln - glutamic acid; Gly - glycine; His - histidine; lle - isoleucine; Leu - leucine; Lys - lysine; Met - methionine; Phe - phenylalanine; Pro - proline; Ser - serine; Thr - threonine; Tyr - tyrosine; Val - valine

\section{CONCLUSIONS}

Investigation of amino acid profiles of four honey types - two monofloral (acacia and sunflower), polyfloral honey (meadow honey) and forest honey (honeydew honey) collected at several locations in the Autonomous Province of Vojvodina (Republic 
of Serbia) indicated that even though honeys have similar amino acid profiles, the application of PCA led to honey differentiation which can be used in distinguishing honey types in terms of their botanical origin. The combination of amino acid analysis together with the determination of other parameters and primarily melissopalynological analysis represents the acceptable method for distinguishing botanical origins of honey.

\section{ACKNOWLEDGEMENTS}

This work was financially supported by the Ministry of Education, Science and Technological Development, Republic of Serbia as a part of the project entitled "Functional Cereal-based Products for People with Metabolic Disorders" (TR31015) and the Provincial Secretariat for Higher Education and Scientific Research, Republic of Serbia [grant number 142-451$2458 / 2018$ ] as a part of the project entitled "Techno-functionality of Proteins from Alternative Plant Sources from Vojvodina Region".

\section{REFERENCES}

1. Alqarni, A.S., Owayss, A.A., Mahmoud, A.A. (2016). Physicochemical characteristics, total phenols and pigments of national and international honeys in Saudi Arabia. Arabian Journal of Chemistry, 9, 114-120.

2. Alvarez-Suarez, J.M., Tulipani, S., Díaz, D., Estevez, Y., Romandini, S., Giampieri, F., Damiani, E., Astolfi, P., Bompadre, S., Battino, M. (2010). Antioxidant and antimicrobial capacity of several monofloral Cuban honeys and their correlation with color, polyphenol content and other chemical compounds. Food and Chemical Toxicology, 48, 2490-2499.

3. Anklam, E. (1998). A review of the analytical methods to determine the geographical and botanical origin of honey. Food Chemistry, 63, 549-562.

4. Bogdanov, S., Martin, P. (2002). Honey authenticity: a review. Mitteilungen aus Lebensmitteluntersuchung und Hygiene, 93, 232-254.

5. Bucher, E., Kofler, V., Vorwohl, G., Zieger, E. (2004). Das Pollenbild der Sudtiroler Honige, Landesagentur fur Umwelt und Arbeitsschutz Biologishes Labor, p. 677.

6. Cometto, P.M., Faye, P.F., Naranjo, R.D., Rubio, M.A., Aldao, M.A.J. (2003). Comparison of free amino acids profile in honey from three Argentinian regions. Journal of Agricultural and Food Chemistry, 51, 5079-5087.

7. Cotte, J.F., Casabianca, H., Giroud, B., Albert, M., Lheritier, J., Grenier-Loustalot, M.F. (2004).
Characterization of honey amino acid profiles using high-pressure liquid chromatography to control authenticity. Analytical and Bioanalytical Chemistry, 378, 1342-1350.

8. Czipa, N., Borbély, M., Győri, Z. (2012). Proline content of different honey types. Acta Alimentaria, 41, 26-32.

9. da Silva, P.M., Gauche, C., Gonzaga, L.V., Costa, A.C.O. (2016). Honey: Chemical composition, stability and authenticity. Food Chemistry, 196, 309-323.

10. Escuredo, O., Míguez, M., Fernández-González, M., Seijo, M.C. (2013). Nutritional value and antioxidant activity of honeys produced in a European Atlantic area. Food Chemistry, 138, 851-856.

11. Flanjak, I., Strelec, I., Kenjerić, D., Primorac, Lj. (2016). Croatian produced unifloral honey characterized according to the protein and proline content and enzyme activities. Journal of Apicultural Science, 60, 39-480.

12. Girolamo, F.D., D'amato, A., Righetti, P.G. (2012). Assessment of the floral origin of honey via proteomic tools. Journal of Proteomics, 75, 3688-3693.

13. Gok, S., Severcan, M., Goormaghtigh, E., Kandemir, I., Severcan, F. (2015). Differentiation of Anatolian honey samples from different botanical origins by ATR-FTIR spectroscopy using multivariate analysis. Food Chemistry, 170, 234-240.

14. Hermosín, I., Chicón, R.M., Cabezudo, M.D. (2003). Free amino acid composition and botanical origin of honey. Food Chemistry, 83, 263-268.

15. Iglesias, M.T., Martian-Alvarez, P.J., Polo, M.C., Lorenzo, C., Gonzalez, M., Pueyo, E.N. (2006). Changes in the free amino acid contents of honeys during storage at ambient temperature. Journal of Agricultural and Food Chemistry, 54, 9099-9104.

16. Kečkeš, J., Trifković, J., Andrić, F., Jovetić, M., Tešić, Z., Milojković-Opsenica, D. (2013). Amino acids profile of Serbian unifloral honeys. Journal of the Science of Food and Agriculture, 93, 3368-3376.

17. Lazarević, K.B., Andrić, F., Trifković, J., Tešić, Ž., Milojković-Opsenica, D. (2012). Characterisation of Serbian unifloral honeys according to their physicochemical parameters. Food Chemistry, 132, 2060-2064.

18. Lee, C.Y., Smith, N.L., Kime, R.W., Morse, R.A. (1985). Source of the honey protein responsible for apple juice clarification. Journal of Apiculture Research, 24, 190-194.

19. Moore, P.D., Webb, J.A. (1978). An illustrated guide to pollen analysis, Hodder \& Stoughton, London, p. 133.

20. Pawlowska, M. Armstrong, D.W. (1994). Evaluation of enantiometric purity of selected amino acids in honey. Chirality, 6, 270-276.

21. Rebane, R., Herodes, K. (2008). Evaluation of the botanical origin of Estonian uni- and polyfloral honeys by amino acid content. Journal of Agricultural and Food Chemistry, 56, 10716-10720. 
22. Reille, M. (1995). Pollen et spores d'Europe et d'Afrique du nord, Laboratoire de Botanique et Palynologie, Marseille, p. 328, Supplement 1.

23. Reille, M. (1998). Pollen et spores d'Europe et d'Afrique du nord, Laboratoire de Botanique et Palynologie, Marseille, p. 523, Supplement 2.

24. Reille, M. (1999a). Pollen et spores d'Europe et d'Afrique du nord, Laboratoire de Botanique et Palynologie, Marseille, p. 243, Index.

25. Reille, M. (1999b). Pollen et spores d'Europe et d'Afrique du nord, Laboratoire de Botanique et Palynologie, Marseille, p. 535.

26. Sakač, M., Jovanov, P., Marić, A., Pezo, L., Kevrešan, Ž., Novaković, A., Nedeljković, N. (2019). Physicochemical properties and mineral content of honey samples from Vojvodina (Republic of Serbia). Food Chemistry, 276, 15-21.

27. Sanz, M.L., del Castillo, M.D., Corzo, N., Olano, A. (2003). 2-furoylmethyl amino acids and hydroxymethylfurfural as indicators of honey quality. Journal of Agricultural and Food Chemistry, 51, 4278-4283.
28. Spackman, D.H., Stein, W.H., Moose, S (1958). Automatic recording apparatus for use in the chromatography of amino acids. AnaIytical Chemistry, 30, 1190-1206.

29. STATISTICA (Data Analysis Software System) (2010). v. 10.0., Stat-Soft Inc., USA. (www.statsoft.com).

30. Sun, Z., Zhao, L., Cheng, N., Xue, X., Wu, L., Zheng, J., Cao, W. (2017). Identification of botanical origin of Chinese unifloral honeys by free amino acid profiles and chemometric methods. Journal of Pharmaceutical Analysis, 7, 317-323.

31. Von der Ohe, W., Oddo, L.P., Piana, M.L., Morlot, M., Martin, P. (2004). Harmonized methods of melissopalynology. Apidologie, 35, S18-S25.

32. Zhao, H., Cheng, N., Zhang, Y., Sun, Z., Zhou, W., Wang, Y., Cao, W. (2018). The effects of different thermal treatments on amino acid contents and chemometric-based identification of overheated honey. LWT- Food Science and Technology, 96, 133-139.

\title{
ПРОФИЛ СЛОБОДНИХ АМИНОКИСЕЛИНА УЗОРАКА МЕДА ИЗ ВОЈВОДИНЕ (РЕПУБЛИКА СРБИЈА)
}

\author{
Маријана Б. Сакач ${ }^{1}$, Павле Т. Јованов ${ }^{1}$, Александар 3. Марић ${ }^{1}$, Зорица М. Томичић ${ }^{1}$, \\ Лато Л. Пезо ${ }^{2}$, Тамара Р. Дапчевић Хаднађев ${ }^{1}$, Александра Р. Новаковић ${ }^{1}$ \\ ${ }^{1}$ Универзитет у Новом Саду, Научни институт за прехрамбене технологије у Новом Саду, \\ 21000 Нови Сад, Булевар цара Лазара бр. 1, Србија \\ ${ }^{2}$ Универзитет у Београду, Институт за општу и физичку хемију, \\ 11000 Београд, Студентски трг бр. 12/V, Србија
}

Сажетак: Аминокиселински профил четири врсте меда - два монофлорална (багремов и сунцокретов мед), полифрлоралног (ливадски мед) и шумског меда (медљиковац), сакупљених са територије Аутономне Покрајине Војводине (Република Србија), одређен је применом јоноизмењивачке хроматографије. Резултати су указали да је пролин доминантна аминокиселина у свим испитиваним узорцима меда. Аминокиселине које су, такође, присутне у значајним количинама су глутаминска киселина > фенилаланин > глицин $\geq$ серин у узорцима багремовог и ливадског меда, док је сунцокретов мед одликовало присуство веће количине аланина у односу на серин. Узорци шумског меда садржали су највише пролина и одликовао их је највиши садржај укупних аминокиселина. Узорци меда класификовани су на основу садржаја аминокиселина применом хемометријских метода (кластер анализа (cluster analysis - CA) и анализа главних компоненти (principal component analysis - PCA)). Кластер анализа различитих врста меда указала је на могућност груписања неких врста меда у односу на остале. Применом PCA узорци различитих врста меда јасно су се издвојили формирајући одговарајуће групе, те се, стога, аминокиселински профрил узорака може искористити као индикатор ботаничке врсте меда.

Кључне речи: мед, аминокиселине, ботаничко порекло

Received: 22 May 2019

Received in revised form: 21 August 2019

Accepted: 9 September 2019 